\title{
Meta
}

Journal des traducteurs

Translators' Journal

\section{Think-aloud Protocols - A Useful Tool for Investigating the Linguistic Aspect of Translation}

\section{Alexander Künzli}

Volume 54, numéro 2, juin 2009

URI : https://id.erudit.org/iderudit/037684ar

DOI : https://doi.org/10.7202/037684ar

Aller au sommaire du numéro

Éditeur(s)

Les Presses de l'Université de Montréal

ISSN

0026-0452 (imprimé)

1492-1421 (numérique)

Découvrir la revue

Citer cette note

Künzli, A. (2009). Think-aloud Protocols - A Useful Tool for Investigating the Linguistic Aspect of Translation. Meta, 54(2), 326-341.

https://doi.org/10.7202/037684ar
Résumé de l'article

Les protocoles de verbalisation ont souvent été utilisés pour étudier la composante cognitive de la traduction. Dans le présent article, nous mettons en évidence leur utilité dans l'étude des problèmes linguistiques liés à l'acte traductif. Les exemples proviennent de données réunies au cours de 40 expériences réalisées avec la méthode du raisonnement à voix haute. Les participants étaient soit des traducteurs professionnels, soit des étudiants en traduction. Les couples de langues étudiés sont français-allemand et français-suédois. Les problèmes linguistiques traités peuvent être classés dans les catégories suivantes : a) grammaticale (l'interprétation des propositions participiales en français) ; b) textuelle (l'utilisation des connecteurs) ; c) fonctionnelle (expression différente d'une même fonction linguistique en français et en allemand ou en suédois) ; d) sociolinguistique (la traduction de la forme de politesse vous française par le vouvoiement $n i$ ou le tutoiement $d u$ en suédois).
Ce document est protégé par la loi sur le droit d'auteur. L'utilisation des services d’Érudit (y compris la reproduction) est assujettie à sa politique d'utilisation que vous pouvez consulter en ligne.

https://apropos.erudit.org/fr/usagers/politique-dutilisation/ 


\title{
Think-aloud Protocols - A Useful Tool for Investigating the Linguistic Aspect of Translation'
}

\author{
ALEXANDER KÜNZLI \\ Zurich University of Applied Sciences, Winterthur, Suisse \\ alexander.kuenzli@zhaw.ch
}

\begin{abstract}
RÉSUMÉ
Les protocoles de verbalisation ont souvent été utilisés pour étudier la composante cognitive de la traduction. Dans le présent article, nous mettons en évidence leur utilité dans l'étude des problèmes linguistiques liés à l'acte traductif. Les exemples proviennent de données réunies au cours de 40 expériences réalisées avec la méthode du raisonnement à voix haute. Les participants étaient soit des traducteurs professionnels, soit des étudiants en traduction. Les couples de langues étudiés sont français-allemand et français-suédois. Les problèmes linguistiques traités peuvent être classés dans les catégories suivantes: a) grammaticale (l'interprétation des propositions participiales en français); b) textuelle ('utilisation des connecteurs); c) fonctionnelle (expression différente d'une même fonction linguistique en français et en allemand ou en suédois); d) sociolinguistique (la traduction de la forme de politesse vous française par le vouvoiement ni ou le tutoiement $d u$ en suédois).
\end{abstract}

\begin{abstract}
Think-aloud protocols (TAPs) have often been used to study the cognitive aspect of translation. This paper shows their usefulness for investigating the linguistic aspect of translation. Examples are drawn from material collected in 40 think-aloud sessions over several years. The participants were professional translators or trainee translators. The language pairs involved are French-German and French-Swedish. The translational linguistic problems discussed fall into the following categories: a) grammatical (the interpretation of French participial clauses), b) textual (the use of connectors), c) functional (different realizations of one and the same linguistic function in French on the one hand, and in German and Swedish on the other), and d) sociolinguistic (the rendering of the formal vous into Swedish by the more formal ni or the less formal $d u$ ).
\end{abstract}

\section{MOTS-CLÉS/KEYWORDS}

protocoles de verbalisation, raisonnement à voix haute, compétence linguistique traductionnelle, traducteurs professionnels, français-allemand, français-suédois

think-aloud protocols, translational linguistic competence, professional translators, French-German, French-Swedish

\section{Conceptual frame of reference}

The goal of this paper is to illustrate that think-aloud protocols of translation processes are a useful tool for investigating the linguistic aspect of translation. Think-aloud protocols - TAPs - are collected by asking someone to perform a task while thinking 
aloud; in our case mostly translating. Until quite recently, TAPs were primarily used to study cognitive processes in translation. Research projects were conducted to examine such questions as: into what phases can we divide the translation process, how much time does the translator invest in reading, writing and revising the source and target texts, how do we define the concepts of translation strategy and translation principle, and are there any differences between trainee translators and professional translators in the translation process (Gerloff 1988; Jääskeläinen 1999; Krings 1986; Lörscher 1991; Tirkkonen-Condit 1997). It is only when process researchers began looking more systematically into the results of the translation process, in other words, the written translations produced by the participants in these studies, that they became increasingly interested in translation problems that might have been triggered by the language pair involved. Thus, Audet and Dancette (2005) studied four translators' sensitivities to literariness in the translation of a Hungarian novel into French. Englund Dimitrova (2005) investigated explicitation as a strategy to solve target-language specific problems in Russian-Swedish translation. Trandem (2005) examined eight Norwegian translators' awareness of the animisms present in the French source texts that they were asked to translate; animisms are often considered a prototypical feature of the French language. Finally, in my own TAP research, I studied to what extent the following linguistic phenomena give rise to problems in French-German or French-Swedish translation: the fictitious dialogue between sender and receiver in advertising texts (Künzli 2001), different mechanisms in word formation in Germanic vs. Romance languages (Künzli 2003, 2005a), and the attribution of gender to product names (Künzli 2005b). So far, however, these linguistic phenomena have been studied in isolation. What is lacking is a theoretical framework capable of encompassing the variety of linguistic problems confronting translators.

Cao's (1996) model of translation proficiency offers a theoretical framework for classifying translational language problems verbalized by participants in TAP studies. The model is based on Bachman's (1990) model of communicative language ability and includes three main variables: translational language competence, translational knowledge structures (world knowledge and subject matter knowledge) and translational strategic competence (planning, executing and assessing a translation task). Within the variable of translational language competence, Cao (1996) mentions on the one hand a sound knowledge of lexis, syntax and the semantic rules of both the source and target languages as well as a knowledge of the rules of cohesion (termed organizational competence, comprising a grammatical competence and a textual competence). On the other hand, she mentions the knowledge necessary to perform appropriate linguistic functions in a given context (termed pragmatic competence, comprising a functional competence and a sociolinguistic competence).

In what follows, I illustrate some of the translational language problems encountered by the participants in my studies, as revealed by their TAPs. The interest in conducting this type of linguistic analysis is threefold: (1) to illustrate translational language problems, which may be difficult to identify or explain if we only look at a written translation, (2) to investigate the level of language competence not only in trainee translators, but also in very experienced translators, and (3) to apply TAPs to the study of phenomena that have received comparatively little attention in translation process research. 


\section{Method}

The material included in this paper comes from two sets of experiments: one study on translation, and one study on translation revision. The material from the translation task consists of 20 TAPs from 10 native German speakers and 10 native Swedish speakers. Nine of the participants were trainee translators, 11 were professional translators. The participants were asked to translate a user guide for a telephone with fax and answer-phone function from French into German and from French into Swedish respectively, while thinking aloud (for a detailed description of the experimental procedure, see Künzli 2003: chap. 2). The material from the translation revision task comes from a research project into translation revision with 20 participants: 10 native German speakers and 10 native Swedish speakers. All participants were professional translators. They were asked to revise respectively three German and three Swedish draft translations of three French source texts, while thinking aloud. The texts used include a judicial decision, an instruction manual for an avalanche safety net, and a direct-mail advertisement for wine.

Within the framework of this paper, it is not possible to give excerpts from all 40 think-aloud sessions. Instead, I will focus on four types of translational language problems that could be identified even in the think-aloud protocols of very experienced translators: (1) grammatical: the interpretation of French participial clauses, (2) textual: the use of connectors, (3) functional: different realizations of one and the same language function in French on the one hand, and in German and Swedish on the other, and (4) sociolinguistic: the rendering of the formal vous into Swedish by the more formal $n i$ or the less formal $d u$. The TAP excerpts presented hereinafter were selected because they illustrate different aspects of these translational language problems. Moreover, in order to provide as broad an overview of the material as possible, I will give examples from both projects (translation and translation revision), both language pairs (French-German and French-Swedish) and all three text types used (legal, technical, and advertising).

It must also be reminded that triangulation, i.e., the investigation of one and the same phenomenon by means of different complementary data sources, is generally considered to enhance the trustworthiness of findings in translation process research (see, e.g., Alves 2003). In the two projects presented here, the following data sources were used: (1) think-aloud protocols, (2) logbook documentation, (3) written translations, (4) quality assessments, (5) questionnaires, and (6) interviews. The purpose of the present paper is to demonstrate the usefulness of think-aloud protocols for investigating the linguistic aspect of translation. Therefore, the focus will naturally be on TAP analysis. However, the other data sources will be used to strengthen the plausibility of the conclusions drawn from the data analysis.

\section{Results}

\subsection{Grammatical}

Grammatical competence includes knowledge of vocabulary, morphology and syntax. It governs the choice of words to express specific significations, their forms and their arrangement in utterances to express propositions (Bachman 1990: 87-88). In translation it refers to the mastery of the language code of the source language and the target 
language (Cao 1996: 330). I will illustrate grammatical competence as a subcomponent of translation proficiency by an example regarding syntax: the interpretation of participial clauses in French-German and in French-Swedish translation.

Decades ago, Malblanc (1944) commented on the difference in frequency and distribution of participial constructions in French and in German, showing that the most natural way to render participial clauses into German is by a relative clause, an adverbial clause (generally of time or cause), or two main clauses coordinated with und 'and.' More recently, Grünbeck (1983: 15-16) stressed that in German, participial clauses are subject to a wide range of restrictions. For example, literal translations of absolute participles (see example below) are ungrammatical. This means that if it is often possible for translators to closely follow the structure of the source language and the source text, a possible automatic processing will be interrupted when they are confronted with a participial clause. The following example illustrates this. The task was to translate a user guide from French into German. The excerpt describes the position of the telephone in relation to the outlets to which it must be connected:

French source text:

La petite fiche étant branchée sur le connecteur (C), faites passer le cordon dans le passe-fil (D).

English translation:

With the small pin plugged into the connector (C), pass the cable through the cable guide (D).

\section{Possible German translation:}

Nachdem der kleine Stecker an der Buchse (C) angeschlossen ist, legen Sie das Kabel durch die Kabelführung (D).

The participial clause étant branchée cannot be literally translated into German. The translator has to make explicit the logical link between the subordinate clause and the main clause, for instance by means of a temporal clause introduced by nachdem 'after' (as in the example above) or a causal clause introduced by weil 'because' or $d a$ 'since.' The following TAP excerpt shows how time-consuming this type of processing can be: ${ }^{2}$

\section{[1] Sophia $(S)^{3}$}

and weil [because] the the pin / pin / weil [because] the pin / is plugged into this connector / you have to pass the cable / through the cable guide ... la petite fiche étant branchée sur le connecteur als [when] da [since] the pin is plugged into the connector C / ... um does this étant mean / weil [because] it is plugged? / I mean it's not causal I mean it's not weil [because] it is / plugged / that you now can / oh! faites passer le cordon dans le passe-fil / is it maybe the other end that you then have to pass through $\mathrm{D}$ ? ... la petite fiche étant branchée sur le connecteur um the pin / is already plugged into the connector / faites passer le cordon / dans le passe-fil / and now? / la petite fiche étant branchée sur le connecteur / faites passer um weil [because] / the pin of the power supply unit / is plugged / into the connector C / or nachdem [after] it is plugged you have to connect the cable / into the cable guide / and then close it again but ... it also looks so short which means you cannot really / because it can be either causal weil [because] this one is already connected you have to connect the other ... in other words weil [because] it is now plugged you can connect / the other into the cable guide / or nachdem [weil] / the pin / has been plugged into the connector $\mathrm{C}$ although it amounts to the same thing you can simply connect the cable into D ... shall I maintain la petite 
fiche étant branchée sur le connecteur in German? / because I have just written plug the pin of the power supply unit into the connector / which means now you know that it is plugged and anyway there is no connection with / with with what you have to do now with D I think I omit it for the time being

Excerpt [1] gives an indication of the effort this participant and others put into interpreting the logical value of the participial clause la petite fiche étant branchée sur le connecteur. The large number of problem indicators - repeated readings of the participial clause, hesitations, pauses, explicit problem identifications in the form of questions, verbalization of competing translation solutions - reveals that the translation of this type of syntactic construction does not occur automatically. Sophia (S) hesitates between causal and temporal interpretations (weil 'because' and $d a$ 'since' on the one hand; als 'when' and nachdem 'after' on the other) until she finally decides to delete the whole segment. However, the uncertainty markers I think and for the time being suggest that she does not feel she has successfully solved the problem.

If the translator is not able to correctly identify the form or the function of the participial clause then the problem may be complicated. The French to Swedish part of the material contains such evidence. Tegelberg (2005) mentions in her inventory of Swedish university students' major problems with French grammar the translation of non-finite clauses - of which participial constructions are an example - from French into Swedish. The following example comes from Kristina's (T) data. The source text is the same user guide as before:

\section{French source text:}

Intégrant les plus récentes innovations technologiques, cet appareil vous permet de disposer à la fois d'un téléphone, d'un répondeur, d'un fax, d'un copieur, d'une imprimante PC et d'un combiné sans fil.

\section{English translation:}

Integrating the most recent technological innovations, this machine allows you to make use at the same time of a telephone, an answer phone, a fax, a copy machine, a PC printer and a handset.

\section{Kristina's translation:}

Innehållande de allra senaste teknologiska nyheterna, tillåter denna apparatur dig att disponera samtidigt en telefon, en telefonsvarare, en fax, en kopiator, en PC-skrivare och en trådlös telefonlur.

The most natural way to translate the present-participle construction intégrant into Swedish is by means of the coordinating conjunction och 'and' (This machine integrates the most recent technological innovations and offers you...). However, as can be seen above, Kristina's ( $\mathrm{T}$ ) translation follows the source-text structure very closely: she chooses a present participle construction, the result being a translation that is marked as archaic (Eriksson 1998: 165-169). This observation - as well as others, such as the way this translator renders extended noun phrases (Künzli 2005a) - suggests that Kristina ( $\mathrm{T}$ ) does not possess a sufficiently developed grammatical competence allowing her to formulate linguistically accurate sentences when translating from French into Swedish. There are several possible explanations for this observation: (1) Kristina (T) declares that she did not go through any longer formal learning process of the French language, but picked it up mostly informally while working for some years in a French-speaking country, (2) French comes last among her working languages, and (3) her education is in the field of engineering sciences, not in 
translation or linguistics. It is therefore possible that she was never really trained to be aware of this type of translational language problem. The following TAP excerpts suggest that Kristina's (T) problem lies not only in finding a Swedish equivalent for the French intégrer; above all, it lies in interpreting the form and function of participial constructions:

\section{[2] Kristina (T)}

Intégrant integrerat integrerande / innefattande but we can't write that / innehållande (she looks up intégrant in a bilingual dictionary) ... inté- intégr- införlivat innefattande ... we have to check that later

[3] Kristina (T)

the little pin / being plugged (she sighs) branchée is plugged it is plugged plugged / into / the connector C / då [as soon as]!

Excerpt [2] shows that Kristina (T) starts by translating the present participle intégrant by means of a past participle (integrerat), before suggesting a translation by means of a present participle (integrerande). After several pauses, she decides to consult a dictionary. However, she does not look up the verb in its infinitive form (i.e., intégrer), but the participle as it stands in the source text (i.e., intégrant). This behaviour again suggests that Kristina $(\mathrm{T})$ may never have acquired the basic formal knowledge of the syntax of participial clauses in French. Her verbalizations regarding the processing of the participial clause la petite fiche étant branchée sur le connecteur in excerpt [3] strengthen this hypothesis. The production of the translation solution by means of the temporal conjunction $d \stackrel{\circ}{\text { ' }}$ as soon as' seems to be the result of an 'aha!' experience; it seems to come as a surprise to her, as suggested by the stress she puts on $d a ̊$.

Overall, these examples reveal that the extent to which translational language problems are present in the translation process may be underestimated if we only look at the written translation. Indeed, at least as far as the participial clause la petite fiche étant branchée sur le connecteur is concerned, Kristina's translation is correct.

\subsection{Textual}

Textual competence includes knowledge of the conventions for joining sentences together to form a text (Bachman 1990: 88-89, Cao 1996). Knowledge of cohesion is a subcomponent of textual knowledge. It is involved in comprehending the explicitly marked relationships between sentences in the source text and in appropriately reproducing them in the target language. Connectors are devices through which intratextual cohesion can be strengthened.

In the study of translation revision, the revised translations were evaluated by one subject-matter expert for each text. The experts' evaluations indicate that translating connectors is sometimes a challenge: (1) they are often rendered literally, without consideration taken to their function as cohesion-strengthening devices, and/or (2) they are attributed a logical value that is possible in general, but not plausible in context. I will illustrate the difficulty professional translators experience when trying to appropriately reproduce connectors with two examples: the connectors d'autre part and enfin. I will only deal with the French to German part here. Let us start with the connector d'autre part, used in the legal text: 


\section{French source text:}

Dans ces circonstances, les demandeurs ont eu de bonnes raisons de considérer que le quorum aurait pu être atteint si les choses s'étaient passées naturellement. Ils n'ont d'autre part que pu être confortés dans le sentiment que $\mathrm{X}$ manquait d'égards envers eux, et qu'elle avait agir [sic] de concert avec les majoritaires, du moins avec ceux d'entre eux qui s'étaient joints à elle pour solliciter l'intervention de Me Y.

\section{English translation:}

Under these circumstances, the plaintiffs had good reasons to believe that the quorum could have been reached if things had gone naturally. They could d'autre part [literally on the other hand, in context moreover] only be strengthened in the feeling that X lacked respect for them and that she had acted concertedly with the majority, at least with those among them that had joined her to solicit the intervention of Maître Y.

\section{German draft translation:}

Unter diesen Umständen konnten die Kläger mit guten Gründen annehmen, dass das Quorum hätte erreicht werden können, wenn alles mit rechten Dingen zugegangen wäre. Andererseits wurden sie in ihren Gefühlen bestärkt, dass X zuwenig [sic] Rücksicht auf sie nahm und im Einvernehmen mit der Mehrheit gehandelt hat, zumindest mit dem Teil, der sich ihr angeschlossen hatte, um das Eingreifen von RA Y zu fordern.

As can be seen, d'autre part has been translated literally by andererseits 'on the other hand.' This is an appropriate solution in many cases, but not here. Andererseits suggests the idea of a contrast. Weinrich (1993: 604) classifies it among the adversative nexus adverbs by which writers express that a counterargument will yet have to be taken into consideration. As for the French d'autre part, when used on its own rather than in combination with d'une part ('on the one hand ... on the other hand), it has the meaning of moreover (Nouveau Petit Robert 1996). It announces that information will be added in the form of yet another element in an enumeration. Riegel et al. (1999: 618-623) include d'autre part among the connecteurs énumératifs 'enumerating connectors.' This category comprises both connectors specific to this category and connectors borrowed from other categories. According to Riegel et al. (1999: 619), d'autre part is borrowed from the category spatial connectors, often used in argumentative texts for contrasting. Here, used as an enumerative connector, it announces an additional argument, not a counterargument.

Several participants replace andererseits by a coherence-strengthening connector such as ausserdem or zudem 'moreover.' More interestingly, the TAPs reveal that some of them refrain from doing so although they explicitly express their dissatisfaction with andererseits:

[4] Chiara (T)

andererseits [on the other hand] they were strengthened in their feelings / under these circumstances they ... / they were why andererseits [on the other hand]? they were / they were ausserdem [moreover] oh strengthened in their feelings

[5] Emma (T)

andererseits [on the other hand] / they were strengthened in their / their feelings in their feeling / um andererseits [on the other hand] einerseits [on the one hand] andererseits [on the other hand] is not logical here / zudem [moreover] / zudem [moreover] ausserdem [moreover] they were strengthened in their / feeling 


\section{[6] Lisa ( $\mathrm{T})$}

andererseits [on the other hand] um but there is no einerseits [on the one hand] / oh puh! I have a bit of a problem with this andererseits [on the other hand] if there is no einerseits [on the one hand] then that bothers me / it says ils n'ont d'autre part yes but there is no d'une part [on the one hand] / nowhere does it say d'une part [on the one hand] well it is / um

The TAP excerpts contain several linguistic markers of the translators' uncertainty, such as explicit questions ("why andererseits?"), admissions of lack of knowledge ("I have a bit of a problem") and truncations ("well it is..."), as well as hesitations ("um"). Excerpt [6] shows that Lisa (T) - rightly - points out that andererseits is often used in the combination with einerseits ('on the one hand ... on the other hand'). In other words, she is bothered by the interpretation of d'autre part as an adversative connector but refrains from making a change. This behaviour suggests that translators do not always rely on their language intuition or on their logical reasoning.

Emma's (T) TAP excerpt reveals a further interesting phenomenon. It indicates that Emma's (T) problem lies not in comprehending the logical value of the connector, but in appropriately reproducing it in the target language. Indeed, her hesitation is in the first place between the competing translation variants zudem and ausserdem. Emma (T) is on the whole more efficient than many of her colleagues in identifying connectors in the German draft translations that do not appropriately convey the functions that the authors of the French source texts in all likelihood attributed to them. She does so although she works mostly from English into German, in contrast with her colleagues, who are specialized in French-German translation. This indicates that a lack of experience in a given language pair is neither automatically nor in all respects associated with lower quality.

Let us look at a second example: the use of the connector enfin in the advertising text:

\section{French source text:}

Enfin, comme vous appréciez également nos grands crus du pays de Vaud, nous vous proposons les vins réputés de trois domaines et châteaux vaudois en offres exceptionnelles de printemps.

\section{English translation:}

Enfin [literally finally, in context last but not least], since you also appreciate our grands crus from the Canton of Vaud, we propose to you the renowned wines from three domains and castles from Vaud as exceptional spring offers.

\section{German draft translation:}

Da Sie schliesslich auch unsere grossen Waadtländer Weine schätzen, bieten wir Ihnen die berühmten Weine von drei Lagen und Châteaux als Frühjahrsangebot an.

As can be seen, enfin has been rendered literally by schliesslich. According to Riegel et al. (1999: 618-623) enfin belongs to the category of temporal connectors, used primarily to mark a chronological succession. However, apart from their use in narrative structures, temporal connectors are used in enumerations to develop a series of elements. In this latter case, enfin marks the conclusion of a series, the peak. Therefore, in German, last but not least (a loan expression from English) is a more appropriate translation than schliesslich. The subject-matter expert's evaluation strengthens this hypothesis. He stresses that the paragraph reproduced above represents the point at which the winery's strategy to induce potential customers to 
respond to its offers reaches its peak. It had previously proposed a selection of wines from California and Spain, before moving on to the exclusive wines from winegrowing estates and castle grounds in Vaud - a region renowned for its wine production in French-speaking Switzerland. Furthermore, the appearance of schliesslich in the middle of the sentence is not unproblematic. Weinrich (1989: 323) remarks, regarding the position of connectors, that fronting entails a certain accumulation of expectancy. In French, enfin is placed at the beginning of the sentence; it even introduces a new paragraph. In the German draft translation, schliesslich appears in the middle of the sentence. Not only is the expectancy effect lost, it even makes its interpretation slightly ambiguous: schliesslich could be interpreted as a concessive connector, meaning immerhin 'still' or 'at least' (Duden Stilwörterbuch 1997). The following TAP excerpts reveal some participants' reactions:

\begin{abstract}
[7] Allegra (T)
schliesslich [finally] since you also appreciate our grands crus from the Canton of Vaud / oh god oh god oh god schliesslich [finally] comme vous appréciez également nos grands vins / nous vous proposons les vins réputés de trois domaines et châteaux vaudois en offres exceptionnelles de printemps / since you I'll delete schliesslich [finally] / since you also I'll delete it because it's simply too fu- too fussy too bureaucratic / since you also appreciate our grands / okay now let's make this a bit / a bit um / a bit ... a bit um softer
\end{abstract}

[8] Lisa $(\mathrm{T})$

schliesslich [finally] since you also / since you / I'll delete schliesslich [finally] since you also appreciate our grands crus from Vaud ... since you / yes schliesslich [finally] is a francisism / since you also appreciate our grands crus from Vaud

[9] Yannic (T)

enfin / enfin / this means we're getting to the end / comme vous appréciez également nos grands crus du pays de Vaud / schliesslich [finally] since you schliesslich [finally] / okay / schliesslich [finally] since you also appreciate our grands crus from Vaud / no this schliesslich [finally] / this this ... this is not good schliesslich [finally] since you / since you schliesslich und endlich [when all is said and done] (he laughs) / since you also appreciate our grands crus from Vaud

In excerpt [7], Allegra (T) declares that schliesslich is "too fussy," "too bureaucratic" and that it has to be replaced by a "softer" connector. The verbalisations contain several linguistic markers of her uncertainty in the form of hedges (four occurrences of "a bit"), hesitations ("um") and exclamations ("oh god"). They suggest that this translator feels that schliesslich is not an appropriate solution, but that she does not succeed in finding arguments supporting her intuition. Lisa (T) states in excerpt [8] that schliesslich is "a francisism," an interference, while Yannic's (T) repeated readings of schliesslich reveal his dissatisfaction with the original translator's solution (excerpt [9]). His paralingual behaviour (laughs) accompanying the only alternative translation he produces, i.e., schliesslich und endlich 'when all is said and done,' indicates that he is equally dissatisfied with his own tentative solution. And indeed, Allegra (T), Lisa ( $\mathrm{T}$ ) and Yannic (T) all decide to delete schliesslich - whereas the subjectmatter expert stresses that enfin must not be omitted because of the role it plays to strengthen intratextual cohesion. The elimination of schliesslich in the revised translations can be seen as an initial successful operation to re-establish cohesion. However, it is not followed up by a second operation consisting of producing a more 
appropriate connector. Connectors thus seem to represent a category of linguistic phenomena in which even very experienced translators reveal uncertainties.

\subsection{Functional}

Functional competence is a subcomponent of pragmatic competence. It deals with the relationships between utterances and the acts or functions that writers intend to perform through these utterances (Bachman 1990: 90-94; Cao 1996). In what follows, I will illustrate some of the problems translators experience when two languages have partly different ways to realize the same language function. To do so, I will give examples from the translation of the user guide text.

User guides have three main functions: (1) to provide instructions, (2) to describe the technical properties of the product, and (3) to encourage and motivate the buyer to make the best possible use of the product (Mårdsjö 1992). This last function has received relatively little attention from translation researchers. This is probably because the introduction part of the user guide, in which this motivational function predominates, is not generally considered to raise problems in translation - at least not in comparison with the processing of technical terms. The TAPs reveal, however, that the translation of sequences with a predominantly motivational function does cause headaches for trainee translators and professional translators alike.

Rhetoric plays an important role in these passages. Companies make use of rhetoric strategies to appeal to the emotions and convictions of the customers to induce them to respond in a particular way. Their primary aim is to sell products, but a secondary aim is to make sure that their customers make good use of the product they have purchased and are satisfied with it, so that they remain loyal to the company and convince others to become customers (Mårdsjö 1992: 57-58).

In the introductory part of the French user guide to be translated by the participants in my TAP study, the customers are asked to carefully read this guide:

\section{French source text:}

Afin d'utiliser votre GALEO efficacement et dans les meilleures conditions, nous vous conseillons de lire très attentivement cette notice d'installation rapide, qui a été rédigée spécialement à votre intention.

\section{English translation:}

In order to use your GALEO efficiently and under the best conditions, we recommend that you read very carefully through this quick user guide, which has been written especially for you.

As can be seen, the recommendation is realized by means of the following rhetoric strategies: (1) the fictitious dialogue between nous 'we' (the company) and vous 'you' (the customer), (2) a positive speech act (nous vous conseillons 'we recommend that you'; see Riegel et al. 1999: 586-588), and (3) intensive adjectives and adverbs (dans les meilleures conditions 'under the best conditions,' très attentivement 'very carefully,' spécialement 'especially'; see Noailly 1999: 38). The company's strategy to create closeness with the customer reaches its peak in the relative clause qui a été rédigée spécialement à votre intention 'which has been written especially for you.'

The data show that the processing of this motivational sequence does not raise any comprehension problems. Neither does it lead to any mistranslations. However, it generates a large amount of verbalizations. These verbalizations reveal that the 
participants often react negatively to the (pseudo-) personal tone of the French source text and that they feel obliged to explore translation strategies that allow them to tone it down in German or Swedish. In doing so, they sometimes refer to cultural differences:

[10] Sonja $(\mathrm{T})$

all that waffling must of course be phrased completely differently in German ... let's keep some of the soft soap but not as overwhelmingly as in French

\section{[11] Fanny (T)}

oh now we have that silly little sentence / yes to get we recommend that you read very carefully / that really sounds a bit pompous / um / okay I'll leave the beginning as it is / so that the user realizes aha okay they take care that I can make um the best possible use of everything

[12] Ylva (S)

we propose that you carefully read / I'll write that you carefully ... carefully read that you carefully read this quick guide carefully ... which has been written for you / well um qui a été rédigée spécialement à votre intention I guess that's this flowery / French style isn't it? kind of superfluous (she laughs) / which which well we have written for you / we propose that you carefully read this quick guide which we have written for you

\section{[13] Sanna (S)}

to make the best possible use of your Galeo / um et dans les meilleures conditions / efficacement et dans les meilleures conditions ... let's see if they have something good in Swedish (she consults parallel texts in Swedish) ...... no ... oh! I wonder if we actually have to keep this in Swedish because the French are more complicated than the Swedes when they write this kind of things / before (she sighs) ... before you use / before / how shall I ... read / carefully / through this user guide before / before oh! using / using using (she laughs) the machine ... that's all there is to say in Swedish

The above excerpts illustrate that many participants' decision processes are governed by the conception that German (see excerpts [10] and [11]) and Swedish (see excerpts [12] and [13])-speaking customers expect a more sober tone than the French. Also, one can easily imagine that verbalizations such as those made by Sonja $(\mathrm{T})$ in excerpt [10] ("all that waffle must of course be phrased completely differently in German...") lead to long reformulation phases during which participants check and re-check the acceptability of the different translation solutions in the target culture. The verbalizations above, according to which the French language is overwhelming, pompous, flowery or complicated, can also be interpreted in the light of what Chesterman (1997: 114-115) has termed significance threshold. If translators working from French feel the need to tone down emotiveness when they translate into German or Swedish, then it may be possible that in French you need more to achieve the same effect. In other words, the significance threshold, i.e., the point above which something is thought to be worth saying, might be at a different level in French on the one hand and in German and Swedish on the other.

\subsection{Sociolinguistic}

Sociolinguistic competence enables the translator to use appropriate language in different sociolinguistic contexts (Cao 1996). It includes sensitivity to differences in dialect or variety, sensitivity to naturalness and the ability to interpret cultural refer- 
ences and figures of speech (Bachman 1990: 94-98). In this paper, I would like to discuss sensitivity to differences in register; more specifically, the rendering of the formal vous into Swedish by the more formal $n i$ or the less formal $d u$.

Both French and Swedish potentially have two second-person singular address pronouns. In French, there are two parallel address systems, with either unmarked $\mathrm{T}$ (the less formal $t u$ form) or $\mathrm{V}$ (the more formal vous form). In Swedish, on the other hand, the T form $d u$ has been the general, usual form since the 1960s. In recent years, $\mathrm{V}$ (ni) has started to reappear, at least in service and business situations. Also, to mark politeness, $d u$ and $n i$ can be spelled with capitals (for an overview of the development, see Teleman et al. [1999: 266-270]). The Swedish translator thus has four options to render the French vous: $d u \rightarrow D u \rightarrow n i \rightarrow N i$, going from $d u$ as least formal to $\mathrm{Ni}$ as most formal address pronoun. One can easily imagine that the choice of the appropriate address pronoun may constitute a problem in translation into Swedish. The TAPs illustrate that this choice is often only made after a considerable amount of hesitation. Here are some excerpts from Oscar's (T) TAP (in excerpt [14], Er corresponds to $\mathrm{Ni}$ when used as a direct object):

\section{[14] Oscar (T)}

one thing that strikes me immediately is that they write $\mathbf{N i}$ and Er with capitals and at least $\underline{I}$ think that this is disturbing in this translation / I actually want to get rid of it um I can check in the Swedish writing rules but I mean capital in Ni is excessively polite in Swedish and I think that it gets / a bit too much of this whole academic Ni and Er almost several times in every sentence and these capitals are only disturbing / um / and yes / I don't think I want to have capitals

\section{[15] Oscar (T)}

I wonder if one should not simply and brutally replace Ni with du / even Swedish authorities address Swedes with du / one should actually / adapt such a text to the target culture / I am going to check again under Ni and du (he consults the Swedish writing rules) The Swedish Language Council does not comment on the use of Ni and du / no of course not ... (he sighs) I decide to replace all Ni with du / it's more natural it's so incredibly pompous otherwise

[16] Oscar (T)

I'll just go through it once again to check if I always use the same address form

The TAP excerpts above reveal that the problem of finding the appropriate address pronoun is present in all phases of the revision process (Oscar [T] is revising someone else's draft translation). Excerpt [14] shows that after having read the source text and the draft translation once, Oscar (T) hesitates between capital letters and small letters on the formal Swedish $\mathrm{Ni}$. Then, during the main evaluation phase (excerpt [15]), he considers replacing $N i$ with $d u$. Finally, he dedicates an entire reading phase in the end just to check whether he has systematically used the same second-person pronoun and lower case throughout (excerpt [16]).

Excerpt [15] also reveals that at one point Oscar (T) consults the Swedish writing rules (Svenska skrivregler 2000), a guide with which almost all translators in Sweden are familiar. It mainly contains rules on spelling and typography. Oscar (T) explicitly expresses his disappointment that it does not offer him any help with the choice of the address pronoun. Indeed, the Swedish Language Council does not give any recommendations for or against the use of the formal Ni. But this type of help would be available in a grammar. The Swedish Academy published a reference grammar in 
1999 (Teleman et al. 1999). It represented the completion of a 200 -year-old project. The grammar includes an interesting overview of the development of the secondperson pronoun in Swedish (Teleman et al. 1999: 266-270), which can help translators in their decision processes. Judging from the TAPs, many translators and trainees are bothered by the $\mathrm{Ni}$ form, without seeming to be able to exactly identify what bothers them and thus find a satisfying solution. Interestingly, however, none of the participants in the TAP studies consulted a grammar during the execution of the different translation or translation revision tasks.

The TAP analysis above once again allowed the identification of a translational language problem that would have gone unnoticed if we had only looked at the written translation: Oscar's ( $\mathrm{T}$ ) decision to render the French vous by $d u$ can be regarded as the most natural solution. More importantly, it contributed to highlighting the specific needs translators may have in the translation process.

\section{Discussion}

The findings from the think-aloud protocol studies presented in this paper reveal that translational language problems play an important role in the translation process - even in that of very experienced translators. Therefore, it is probably a bit unfortunate that the linguistic aspect of translating is somewhat underestimated today, as Albrecht (2005: 11-12) and Schreiber (2004) recently pointed out again. The results also suggest that the identified language problems may at least partly be explained by Cao's (1996) model of translation proficiency, adapted from Bachman (1990), and more specifically in terms of variations in specific components of translational language competence.

Where to go next? TAPs appear very useful for investigating the translator's variability. To my knowledge, there have not yet been any TAP studies in which intra-individual variability was assessed by asking participants to translate from and into different languages. It seems safe to assume that translating from one's second language is generally less effortful than translating from one's third or fourth language. However, there seem to be instances in which a lack of translational experience in a specific language pair is not necessarily detrimental. Thus, the TAP study on translation revision suggests that Emma, a professional translator working almost exclusively from English into German, was very efficient in identifying and correcting interferences from the French source text in the German draft translations when it came to connectors. She proved herself highly capable of hearing what sounds most natural in German in this respect. Maybe her relative lack of exposure to structures that are typical of the French language allowed her to maintain a greater distance from the source text. Naturalness of language use is mentioned among the subcomponents of sociolinguistic competence in Bachman's (1990) and Cao's (1996) models. Greater experience in one language pair does not seem to correlate with better performance in every respect. More research effort is needed to shed light on the correlation among translational language competence, experience of translation, and quality.

The findings also suggest the usefulness of designing continuous training courses for professional translators. As we have seen, an education in the field of engineering sciences does not amount to the same thing as being able to provide quality in tech- 
nical translation. However, commissioners of technical translations often seem to give priority to extra-linguistic knowledge (documented, e.g., in the form of a technical education), to the detriment of an education in the field of translation or linguistics. Offering training courses in contrastive linguistics geared towards the solution of translation problems in a given language pair would allow translators with a technical background to rapidly raise their translational language competence, speed up their translation processes and heighten their self-confidence as language experts. The data show that even in technical translation, language-pair related translation problems continue to be omnipresent.

Finally, the results also suggest that translators benefit from training courses in how to use grammars as a resource in the translation process. As I mentioned, none of the participants in the TAP studies consulted a grammar during task execution. Engdahl and Norén (2000) showed that sometimes practical issues such as the size of a book deter potential users from consulting it - the Swedish Academy Grammar (Teleman et al. 1999) is 2,700 pages. Therefore, they designed a course for students in linguistics, teaching them how to find their way in and through this reference grammar. A similar course could be offered for practising translators, with a focus on the help the grammar offers regarding style, language variation, register and norm. Every time leading translation software companies release a new product, translators' associations send out information and offers for training courses, so that their members remain up-to-date on the latest technological tools. Perhaps they should also consider offering similar courses allowing their members to keep up-todate on important releases of grammars and other linguistic information sources. The publication of a reference grammar a country has awaited for two hundred years is probably such an event.

\section{NOTES}

1. Research support from the Bank of Sweden Tercentenary Foundation (Reg. no. J2004-0368) is gratefully acknowledged. I would also like to thank Jennifer Evans for editing my English.

2. I have translated the verbalizations into English. However, source-text segments verbalized by the participants in French are maintained in French. Also, some verbalizations made by the participants in German or in Swedish such as tentative translation solutions are maintained in these languages. This paper deals with translational language problems. Certain hesitations of the participants between different linguistic items have no equivalence in English. I believe, however, that the comments following the TAP excerpts will allow the reader who is not familiar with either German or Swedish to follow the line of thought. In the TAP excerpts, the elements commented on are put in bold; their English translation generally follows in square brackets.

3. Henceforth, I will use the abbreviation "S" for student and "T" for translator.

\section{REFERENCES}

Albrecht, Jörn (2005): Übersetzung und Linguistik. Tübingen: Narr.

Alves, Fabio, ed. (2003): Triangulating translation: Perspectives in process oriented research. Amsterdam: John Benjamins.

Audet, Louise and DANCETte, Jeanne (2005): Le mouvement de la création dans la traduction littéraire. In: Alexander KüNZLI, ed. Empirical research into translation and interpreting: Processes and products, Bulletin suisse de linguistique appliquée. 81:5-24.

Bachman, Lyle F. (1990): Fundamental considerations in language testing. Oxford: Oxford University Press.

CAO, Deborah (1996): Towards a model of translation proficiency. Target. 8(2):325-340. 
Chesterman, Andrew (1997): Memes of translation. The spread of ideas in translation theory. Amsterdam: John Benjamins.

Duden. Das Stilwörterbuch (1997): Mannheim: Dudenverlag.

ENGDAHL, Elisabeth and Norén, Kerstin (2000): Svenska Akademiens grammatik - en resurs för forskning och undervisning [The Swedish Academy Grammar - A resource for research and teaching]. Språk och Stil. 10:165-195.

Englund Dimitrova, Birgitta (2005): Combining product and process analysis: Explicitation as a case in point. In: Alexander KüNZLI, ed. Empirical research into translation and interpreting: Processes and products. Bulletin suisse de linguistique appliquée. 81:25-39.

ERIKsson, Olof (1998): Presensparticipet i svenskan och franskan. En jämförande studie av syntaktisk distribution [The present participle in Swedish and in French. A contrastive study of syntactic distribution]. In: Olof ERIKsson, ed. Språk- och kulturkontraster. Om översättning till och från franska [Linguistic and cultural contrasts. On translation into and from French]. Åbo: Åbo Akademis Förlag, 151-169.

Gerloff, Pamela (1988): From French to English: A look at the translation process in students, bilinguals and professional translators (Unpublished doctoral dissertation). Harvard: Harvard University.

GRÜNBECK, Bernhard (1983): Moderne deutsch-französische Stilistik auf der Basis des Übersetzungsvergleichs. Heidelberg: Carl Winter Universitätsverlag.

JäÄSKELÄINEN, Riitta (1999): Tapping the process: An exploratory study of the cognitive and affective factors involved in translating (University of Joensuu Publications in the Humanities 22). Joensuu: University of Joensuu.

KRINGS, Hans P. (1986): Was in den Köpfen von Übersetzern vorgeht. Eine empirische Untersuchung zur Struktur des Übersetzungsprozesses an fortgeschrittenen Französischlernern. Tübingen: Narr.

KüNZLI, Alexander (2001): Experts vs novices: La traduction du dialogue fictif dans les textes publicitaires. Babel. 47(4):323-342.

KüNZLI, Alexander (2003): Quelques stratégies et principes en traduction technique françaisallemand et français-suédois (Cahiers de la recherche 21). Stockholm: Stockholm University, Department of French, Italian and Classical Languages, <www.diva-portal.org >.

KüNZLI, Alexander (2005a): Investigating translation proficiency - A study of the knowledge employed by two engineers in the translation of a technical text. In: Alexander KüNZLI, ed. Empirical research into translation and interpreting: Processes and products. Bulletin suisse de linguistique appliquée. 81:41-56.

KüNZLI, Alexander (2005b): Le traitement des noms de produits dans la traduction françaisallemand. The Journal of Specialised Translation. 4:34-49.

LÖRSCHER, Wolfgang (1991): Translation performance, translation process, and translation strategies. A psycholinguistic investigation. Tübingen: Narr.

Malblanc, Alfred (1944): Stylistique comparée du français et de l'allemand. Paris: Didier.

MÅRDsJö, Karin (1992): Människa, text, teknik - tekniska handböcker som kommunikationsmedel [Humans, text, technology - Technical handbooks as a means of communication] (Linköping Studies in Arts and Science 82). Linköping: Tema Teknik och social förändring, Universitetet i Linköping.

NoAilly, Michèle (1999): L’adjectif en français. Paris: Ophrys.

Nouveau Petit Robert. Dictionnaire alphabétique et analogique de la langue française (1996) (electronic version). Paris: Dictionnaires Le Robert.

Riegel, Martin, Pellat, Jean-Christophe and Rioul, René (1999): Grammaire méthodique du français. Paris: PUF.

SCHREIBER, Michael (2004): Kontrastive Linguistik und sprachenpaarbezogene Translationswissenschaft. In: Gyde Hansen, Kirsten MalmkjÆr and Daniel Gile, eds. Claims, changes and challenges in translation studies: Selected contributions from the EST Congress, Copenhagen 2001. Amsterdam: John Benjamins, 83-98. 
Svenska skrivregler [Swedish writing rules] (2000): $2^{\text {nd }}$ ed. Stockholm: Svenska språknämnden and Liber.

TEGELbERG, Elisabeth (2005): Vad är svårt i fransk grammatik? En resonerande inventering av svenska studerandes problem i fransk grammatik [What is difficult in French grammar? An annotated inventory of Swedish university students' problems with French grammar] (Opuscula Romanica III). Gothenburg: Gothenburg University, Department of Romance Languages.

Teleman, Ulf, Hellberg, Staffan and Andersson, Erik, eds. (1999): Svenska Akademiens grammatik. 2, ord [The Swedish Academy Grammar. Vol. 2, words]. Stockholm: Nordstedts ordbok.

TirkKonen-Condit, Sonja (1997): Who verbalises what - A linguistic analysis of TAP texts. Target. 9(1):69-84.

Trandem, Beate (2005): Discours sur le vif. Étude du processus de traduction des animismes du français en norvégien (Acta Humaniora 219). Oslo: Faculty of History and Philosphy, University of Oslo.

WeInRICH, Harald (1989): Grammaire textuelle du français. Paris: Didier.

WeINRICH, Harald (1993): Textgrammatik der deutschen Sprache. Mannheim: Dudenverlag. 